\title{
"CONCERNING CHANGE": THE ADOPTION AND IMPLEMENTATION OF THE NEW ZEALAND BILL OF RIGHTS ACT 1990
}

\author{
KJ Keith ${ }^{*}$
}

This article draws on a paper delivered by the author, a Judge of the New Zealand Court of Appeal, to the 10th Anniversary International Conference of the Society for the Reform of Criminal Law, London, 27 July - 1 August 1997. In it, the author comments on the process leading to the enactment of the New Zealand Bill of Rights Act 1990 and its implementation. The origins and basic characteristics of the Act are discussed, and the impact of the Act on the preparation of legislation is explored. The author then considers the impact of the Act on the Courts and raises some important issues and questions regarding the future of the Act.

A little over 25 years ago, Professor John Roberts gave the last of the K J Scott Memorial Lectures. In this tribute to him and his memory, I borrow his title, "Concerning Change", in commenting on the process leading to the enactment of the Bill of Rights and on its implementation. The subject matter more or less chooses itself. It has been addressed by members of the political science department and the law faculty from at least the early 1960s when I first enjoyed the privilege of having John Roberts as a colleague and a friend. They have addressed the issues both while still at the University and after - in submissions

* Judge of the Court of Appeal of New Zealand, Professor Emeritus of Victoria University of Wellington and member of the Law Faculty 1962-1964, 1966-1991. This article draws on a paper delivered to the $10^{\text {th }}$ Anniversary International Conference of the Society for the Reform of Criminal Law, London 27 July - 1 August 1997. I am grateful to Jonathan Boston, Andrew Butler, Ellen France, Janet McLean and Mike Taggart for comments on an earlier draft and to Nicola Grant for her assistance in updating the paper.

1 J L Roberts "K J Scott Memorial Lecture 1973: Concerning Change" (1974) 37 (1) NZJPA 1. For tributes to John and some of his writing, see Margaret Clark (ed) The Roberts Report (Victoria University Press, Wellington, 1999). 
to Parliament, ${ }^{2}$ as scholars, ${ }^{3}$ as advisers to government, ${ }^{4}$ as the Minister responsible for a Bill, as counsel and as judges. As well, some of them have changed their position from opposition to support as has Parliament. ${ }^{5}$

I consider (1) the immediate origins of the Bill of Rights, (2) some of its basic characteristics, (3) its impact on the preparation of legislation, and (4) its impact in the Courts. I conclude with some lessons this brief account may suggest.

\section{THE IMMEDIATE ORIGINS OF THE BILL OF RIGHTS}

In the 1984 electoral campaign the New Zealand Labour Party, then in opposition, emphasised constitutional reform. After being elected to office, and while making huge changes in economic and social policy, it introduced extensive constitutional reform - in the structure of the state (with corporatisation, privatisation, state sector reform and public

2 See the submissions, all against the Bill proposed in 1963 (a Bill which closely followed the Canadian Bill of Rights 1960), made by Professor R H Brookes and Dr A D Robinson of the Political Science Department, and Professor I D Campbell, Professor C C Aikman (for the Wellington District Law Society) and D L Mathieson and the writer, of the Law Faculty. The Solicitor-General, HRCWild QC, also expressed his opposition: "This Bill is not only unnecessary: its enactment would be positively against the public interest". He mentioned that very senior Canadian judges were emphatic in advising against it. "Most recently the Lord Chief Justice of England [Lord Parker] voluntarily raised the matter with me and expressed the fervent hope we would take the matter no further". [1965] AJHR 8, 27, 29, 38 and 52. Those submissions are reprinted in L Cleveland and A D Robinson Readings in New Zealand Government (1972). United Kingdom opinion has also changed as appears especially from the enactment of the Human Rights Act 1998 to give effect to the European Convention on Human Rights, a change generally and strongly supported by senior judges, including successive Chief Justices.

3 The writing can be divided into three periods: (1) the 1960s (relating to the proposals of that time), (2) the 1970s-1980s (especially writing relating to the 1985 proposal) and (3) from 1990 when the Bill was enacted. For a very selective list see for example (1) R G Mulgan, R Q Quentin-Baxter and G W R Palmer in K Keith (ed) Essays on Human Rights (Sweet \& Maxwell, Wellington, 1968) marking the $20^{\text {th }}$ anniversary of the Universal Declaration of Human Rights (the first and second papers focus more on the international texts); (2) K Keith "A Lawyer Looks at Parliament" in Sir John Marshall (ed) The Reform of Parliament: Papers Presented in Memory of Dr Alan Robinson (1978); G Palmer Unbridled Power (1 ed, Oxford University Press, Auckland, 1979); (3) A Butler and A Shaw "Arbitrary Arrest and Detention under the New Zealand Bill of Rights - the New Zealand Courts Stumble in Applying the International Covenant" [1993] NZLJ 139.

4 Including Professor Peter Hogg OC QC, a former member of the Law Faculty, who was able to draw on his unparalleled Canadian experience, for example Constitutional Law of Canada (four editions between 1977 and 1997) and $n 10$ below. In addition to the White Paper and many speeches by Rt Hon Geoffrey Palmer as the responsible Minister, see K Keith "A Bill of Rights for New Zealand? Judicial Review versus Democracy" (1985) 11 NZULR 307.

5 Compare Palmer's 1968 article with his 1979 book and the submissions made by Mathieson and me with my 1976 and 1985 papers. 
finance reform), ${ }^{6}$ open government (with liberalising amendments to the Official Information Act 1982 and its extension to local government), the operation of Parliament (with major changes in standing orders and the select committee system), control over regulation making, the historical claims and constitutional status of Maori, proportional representation and, of course, the introduction of a Bill of Rights.

Some of the immediate reasons for the changes were peculiar to New Zealand. They included the extremes of economic regulation to which the country was subject in the period leading up to the election, the economic difficulties the government faced the day after the election and the relative lack of formal constraints within our constitutional system (and the growing concern about that lack), as well as the opinions and actions of individuals within the Labour Party itself, notably Geoffrey Palmer who was to become deputy Prime Minister, Attorney-General, Minister of Justice and Leader of the House for most of the six years of the Labour government. ${ }^{7}$ But other reasons for the reforms were, and are, more general and more enduring, including changes in the role of the state resulting from amazing technological and scientific development, ideological change and growing globalisation. ${ }^{8}$

In the human rights area, the reasons for reform focused on the virtually unlimited powers of Parliament and the government, especially in a parliamentary system of government, the extensive role of the state, the limited controls on the exercise of parliamentary and governmental powers, the danger of erosion of human rights, the danger of waiting (an insurance policy cannot be bought after the house has been burned down), the enhancing of accountable and democratic government, the implementation of New Zealand's international obligations and the example of others. Another particular

6 For example John Roberts Politicians, Public Servants and Public Enterprise (Victoria University Press for the Institute of Policy Studies, Wellington, 1987).

7 In the second edition of his book Unbridled Power (2 ed, Oxford University Press, Auckland, 1987) he includes the Labour Party policy on these matters. The first edition was published on the day in 1979 when he received the nomination for a Parliamentary seat and began his move from the law faculty of the Victoria University of Wellington to Parliament. The latest edition, co-authored by his son Dr Matthew Palmer (also a graduate and former law faculty member at Victoria University of Wellington), was published in 1997 under a new title, Bridled Power, which reflects something of the results of Sir Geoffrey's work.

8 For an excellent book on those themes see Susan Strange The Retreat of the State: the Diffusion of Power in the World Economy (Cambridge University Press, New York, 1996). I have addressed some of the legal issues in "Sovereignty: A Legal Perspective" in G A Wood and L S Leland Jr (eds) State and Sovereignty: Is the State in Retreat? (University of Otago Press, Dunedin, 1997). 
reason related to the constitutional recognition and affirmation of the rights of Maori under the Treaty of Waitangi. ${ }^{9}$

I begin with the example of others since in the end the principal text for those who worked on the 1985 proposals was the Canadian Charter of Rights and Freedoms of 1982. The rights included in that initial proposal closely matched those in the Canadian model (with some important exceptions), ${ }^{10}$ the drafting was similar and the Bill was to be entrenched. As the Long Title to the Bill as enacted makes clear, the International Covenant on Civil and Political Rights also played a significant role in the preparation of the text, although there are differences in scope and drafting between the Covenant and the Bill as it was finally enacted.

The entrenchment provision would have prevented the repeal of, or amendment to, any provision of the Bill of Rights unless the proposal (1) had been passed by a majority of 75 per cent of all the members of the House of Representatives, or (2) had been carried by a referendum of the electorate. That formula was based on the provision included in New Zealand's electoral law since 1956 to protect certain core features of the electoral system but with the notable difference that it also purported to protect itself. By contrast the entrenching provision in the 1956 and 1993 Electoral Acts could apparently be repealed first and the no longer protected provisions could then be repealed, in both cases by an ordinary simple majority vote. Even if that may be so as a matter of law, convention strongly supports the protection. ${ }^{11}$

9 This paragraph repeats headings from the chapter headed "Why Does New Zealand need a Bill of Rights?" in A Bill of Rights for New Zealand - a White Paper [1985] AJHR A5 [White Paper].

10 The New Zealand Bill does not include the broad right not to be deprived of liberty except in accordance with principles of fundamental justice included in s 7 of the Canadian Charter (compare s 8 of the New Zealand Bill) nor the general equality guarantees of s 15 (compare s 19). This narrowing, on which Professor Peter Hogg gave valuable advice, was part of an attempt to give the Bill a process emphasis and to lessen the prospect of the courts entering into substantive due process issues; see for example paras 4.13-18 of the White Paper above n 9, and my 1985 article, above $\mathrm{n} 4$. For a valuable related criticism of the inclusion of due process and equal protection provisions in an entrenched Bill of Rights see Frank Brennan "Thirty Years on, do we need a Bill of Rights?" (1996) 18 Adelaide LR 123. On equality and non-discrimination see the differences of view expressed in Quilter v Attorney-General [1998] 1 NZLR 523 (CA).

11 The Royal Commission on the Electoral System in 1986 expressed the opinion, on the basis of principle and practice over the preceding 30 years, that the entrenchment now had conventional protection, Royal Commission on the Electoral System Towards a Better Democracy (Government Printer, Wellington, 1986) 288. The parliamentary and popular referendum process followed in 1992 and 1993 consolidates the convention; see especially the important statement made by the Attorney-General, Paul East, (3 August 1993) 537 NZPD 17140; see also the Introduction to the Cabinet Office Manual (Cabinet Office, Wellington, August 1996) 8. 
The commentary to the proposed Bill of Rights made clear the government's opinion that such an entrenched constitutional status could be achieved both in law and as a matter of convention only if there was clear public support for that step: ${ }^{12}$

A statute of this nature is of such major significance that there needs to be a general consensus amongst the public, both that it is needed and on its content. If this consensus exists, it is far more likely that the courts will rule in favour of effective entrenchment of a Bill of Rights.

The White Paper elaborated on the legal and conventional arguments: 13

One thing must be clearly understood. To protect a Bill of Rights by entrenchment is not an attempt to write our contemporary political and constitutional understandings indelibly on the future. That would display a foolish arrogance that assumes that what we regard as wisdom will hold true for all future generations. History demonstrates quite clearly the falseness of that assumption. To be sure the Bill of Rights is meant to be durable and it should not be easy to change it. To obtain the proposed majority of members of Parliament will normally involve some sort of agreement between the major political parties. Nor in the usual course will it be easy to obtain the support of the majority of electors in a referendum. All this reflects, however, what the proposed Bill of Rights seeks to do. It seeks to enshrine basic rights and freedoms, those things which the great majority of people in our present society see as fundamental. They represent the common understandings of society in this context. Clear support from the public will be essential if the Bill of Rights is to succeed. By the same measure, if it is sought to change those understandings, then those changes too should only be made if there is a similar measure of support in society.

The process followed over the next five years showed beyond any possible doubt that clear public support did not exist for an entrenched Bill. The Select Committee which considered many submissions made in hearings held around the country reported that fact in 1988 and proposed by a majority that the Bill take the form simply of an interpretative statement, with the opposition (National) members of the Select Committee being opposed even to that lesser course. A principal reason for the opposition to an entrenched Bill of Rights was that the Bill would give power to a non-elected, non-accountable and nonrepresentative judiciary. ${ }^{14}$ In the earlier debate in the 1960s members of the law faculty

12 New Zealand Bill of Rights Bill 1990, para 7.19.

13 White Paper above n 9, para 7.20.

14 For a valuable account of the process see Paul Rishworth in P Rishworth and G Huscroft (eds) Rights and Freedoms: the New Zealand Bill of Rights Act 1990 and the Human Rights Act 1993 (Brookers, Wellington, 1995) ch 1. I recommend the book as a whole for its thorough examination of the Bill of Rights and also the Human Rights Act 1993. Sir Geoffrey Palmer provides a most interesting inside account in New Zealand's Constitution in Crisis (McIndoe, Dunedin, 1992) ch 3. 
and political science department consistently made that argument but it appears that in the 1980s no one from that faculty and department repeated it.

The dropping of superior law status was one of two major changes to the 1985 proposal which reduced the force and significance of the Bill. The other was the removal of the provisions recognising and affirming the rights of the Maori people under the Treaty of Waitangi. The government persevered with the reduced measure, introducing it as a Bill in October 1989. It received its third reading ten months later and came into force on 25 September 1990, shortly before the government which had shepherded it through was swept from office at the polls at the end of 1990.

There was some initial question about the attitude of the new government to the new Bill, given its opposition to the proposals, both in the entrenched and interpretative forms. That opposition was in somewhat contradictory terms: either the Bill was a Trojan horse for a later entrenched Bill or it was a "Clayton's" Bill - the Bill of Rights you have when you are not having a Bill, a reference to a non-alcoholic "hard liquor" which soon disappeared from the shelves of New Zealand supermarkets.

Unlike that ill-fated drink, the Bill certainly has not disappeared: according to one computer count there are 2,636 references to it in judgments delivered by the Court of Appeal in just the ten years since it came into force. As I shall mention, the Bill has also had a real impact on the process for the preparation of legislation. That is to say the change in the status of the Bill between its 1985 and 1990 versions has not in my view emasculated it, as some contemporary opinion predicted. ${ }^{15}$

15 See the views assembled by Rishworth, above n 14, 23-25. Some similar later opinion is suggested by the words of the title of one critic, Hart Schwartz "The Short Happy Life and Tragic Death of the New Zealand Bill of Rights" [1998] NZ Law Rev 295. The following nine Court of Appeal judgments given since the article was completed might suggest the obituary was early: Lewis $v$ Wilson \& Horton Ltd (29 August 2000) unreported, Court of Appeal, CA131/00 (order quashing name suppression upheld because there were no grounds which could justify departing from the principle of open justice and the freedom to receive and impart information protected by s 14); Dunlea v Attorney-General (14 June 2000) unreported, Court of Appeal, CA306/98 (awards of damages for breaches of the unreasonable search provision of s 21 and the arbitrary detention provision of s 22 upheld in part); Moonen v Film and Literature Board of Review [2000] 2 NZLR 9 (Board directed to consider censorship classification of a book and photographs on the basis that the Bill of Rights had not been given proper consideration); $R v$ Taliau (30 June 1999) unreported, Court of Appeal, CA99/99 (new trial ordered, in part for breach of appellant's right to silence under s 23(1)(b); Choudry v Attorney-General [1999] 2 NZLR 582 (CA) (the search and seizure provision of s 21 was invoked in support of the conclusion that the Security Intelligence Service had no implied power of entry in support of its power to intercept communications); TV3 Network Service v Fahey [1999] 2 NZLR 129 (CA) (the guarantee of freedom of speech in s 14 supported the proposition that the jurisdiction to issue an interim injunction against a proposed broadcast should be exercised only for clear and compelling reasons); Attorney-General v Upton (1998) 5 HRNZ 54 (compensation award, (1998) 3 HRNZ 179, for breach of right to a fair hearing 


\section{SOME BASIC CHARACTERISTICS OF THE BILL OF RIGHTS}

The general explanation of the effect of the Bill, as with other law, depends partly on its terms and partly on the use that those to whom it is directed make of it. I consider those two matters briefly in this part of the paper and in more detail in the following two parts.

The principal operative provisions of the Bill of Rights are to be found in sections 2 to 7 (see also sections 28 and 29). The Bill affirms the rights and freedoms it sets out (section 2) and applies only to public acts (section 3). The rights and freedoms are not necessarily absolute since they may be subject to such reasonable limits prescribed by law as can be demonstrably justified in a free and democratic society, but only to such limits (section 5). So far the Bill follows the 1982 Canadian model but, in sharp distinction to that measure and the 1985 proposal, it does not provide that any law inconsistent with the Bill is of no effect (section 51(1) of the Canadian Charter and article 1 of the $1985 \mathrm{New}$ Zealand draft Bill). To the contrary, the strongest direction to the courts is that given in section $6:$ a meaning of an enactment consistent with the Bill is to be given if possible.

Any doubt about the maintenance of the powers of future parliaments is removed by section 4 which was added to the Bill in the course of its progress through Parliament to emphasise the relative positions of legislature and court and the subordinate role of the Bill of Rights:

No court shall, in relation to any enactment (whether passed or made before or after the commencement of this Bill of Rights),-

(a) Hold any provision of the enactment to be impliedly repealed or revoked, or to be in any way invalid or ineffective; or

(b) Decline to apply any provision of the enactment-

on sentencing upheld); De Montalk v R (25 June 1998) unreported, Court of Appeal, CA66/98 (new trial ordered for breach of rights to legal representation); Dane $v R$ (25 June 1998) unreported, Court of Appeal, CA195/98 (name suppression refused, s 14 regulating right to impart information). In the following six cases decided by the Court of Appeal in the year before the article was completed the Bill appears to have been significant: Lange $v$ Atkinson [1998] 3 NZLR 424 (s 14 a factor determining scope of freedom of speech in a political defamation case; see also Lange v Atkinson [2000] 1 NZLR 257 (PC) and Lange v Atkinson (21 June 2000) unreported, Court of Appeal, CA52/97), Anderson v R (26 November 1997) unreported, Court of Appeal, CA366/97 (speculative search in breach of $\mathrm{s} 21$ and evidence held inadmissible), $R v J[1998] 1$ NZLR 20 (breach of fair hearing requirement of s 25(a); conviction quashed), Fulcher $v$ AttorneyGeneral (1997) 15 CRNZ 222 (principles underlying prohibition on retrospective criminal laws in s 24(5) invoked in dissent), $R v$ Hines [1997] 3 NZLR 529 (fair trial rights preclude anonymous witnesses), Awa $v$ Independent News Auckland Ltd [1997] 3 NZLR 590 (s 14 supporting freedom of speech in defamation case). 
by reason only that the provision is inconsistent with any provision of this Bill of Rights.

Different views have been expressed about the relationship between sections 6, 5 and $4 .{ }^{16}$ Is it the case that a judge in deciding whether a provision can be interpreted consistently with the rights affirmed in the Bill of Rights must also take into account the justified limitation provision in section 5? As will appear, Attorneys-General in the exercise of their functions under section 7 have taken and do take account of section 5 . One consideration bearing on this matter is that in some circumstances, if not in all, the difference between determining whether the right looked at alone has been breached and the right read with section 5 has been breached may be more one of emphasis than substance. Consider, for instance, the determination of whether a particular statutory power is an exercise of a power of search or seizure or whether it is or is not unreasonable or whether it might or might not be held to be a reasonable limit justified in a free and democratic society. ${ }^{17}$

A final point to be made about the operative provisions is that section 4 , the provision asserting the continuing law-making authority of Parliament, notwithstanding the Bill of Rights, has according to the Law Reports rarely been invoked successfully. One clear situation does however show it having the effect intended by those who inserted it. The Bill of Rights provides that a person charged with an offence has the right to the benefit of a trial by jury when the penalty for the offence includes imprisonment for more than three months (with an exception for military trials). At least two statutory provisions which provide for a penalty of six months deny the right to a jury trial. High Court judges have held that those exclusions override the Bill's right to jury trial. ${ }^{18}$

The remaining principal operative provision of the Bill, also added to the 1985 text (in this case before the Bill was introduced), is section 7 which requires the Attorney-General to report to Parliament on Bills appearing to breach the Bill of Rights. That duty is considered in the next part of this paper.

So much for a brief reference to the operative terms of the measure. What of the attitudes of those to whom it was directed? How have they used it? Again those questions

16 See for example Ministry of Transport $v$ Noort [1992] 3 NZLR 260 (CA) [Noort]; Moonen v Film and Literature Board of Review above n 15 and Rishworth, above n 14, ch 3.

17 See also the discussions of s 5 in the judgments in the High Court and the Court of Appeal in Lange $v$ Atkinson [1997] 2 NZLR 22, 45 (HC) and [1998] 3 NZLR 424, 465-466 (CA) (linking back to the international material).

18 Birch v Ministry of Transport (1992) 9 CRNZ 83 (HC), followed by Reille v Police [1993] 1 NZLR 587 (HC). The rarity of such cases might be explained in significant part by the very existence of s 4 . 
are considered in particular contexts in the next two parts of the paper, but some general comments may be useful.

The first relates to the professional and public understanding of the possible and actual role of the law and in particular of courts in the control of state power. That understanding has altered over recent decades in New Zealand as elsewhere in the common law world in the direction of greater control. Consider the growth of judicial review of administrative action over the last 40 years, along with related legislation concerned, for instance, with the Ombudsman, freedom of information and the control of regulation making.

The New Zealand legal profession, including government lawyers, the judiciary and the academics, have become more and more familiar with the issues of public power not simply as they arise locally but also elsewhere. That understanding has increasingly taken account of international law as human rights treaties have been prepared within the United Nations system and regionally. That international basis for the 1990 Act is made explicit in the title to the Bill of Rights :

An Act

(b) To affirm New Zealand's commitment to the International Covenant on Civil and Political Rights

It does, however, have to be said that the growth in New Zealand of the understanding of the role of international law in our national legal system has been slow and uneven. We are not alone in that. Judge Rosalyn Higgins, drawing on her extensive experience as counsel in domestic and international courts, as a member of the Human Rights Committee established under the International Covenant on Civil and Political Rights and as an academic, has commented in a most interesting way on this matter. While her comments appear in the course of a discussion of "the great jurisprudential debate" about the place of international law in national legal processes, she becomes more mundane when she refers to the "the reality of legal culture": ${ }^{19}$

In some jurisdictions international law will be treated as a familiar topic, one that both the judge and the counsel before him will expect to deal with on a routine basis, the introduction of which occasions no special comment or interest. Of course, this attitude is more to be expected in systems accepting the monist view. But I speak of very practical matters: the judge

19 Rosalyn Higgins Problems and Process: International Law and How We Use it (Clarendon Press, Oxford, 1994) 206-207. She focuses her comments by referring in a critical way to the differing cultures seen at various stages of the International Tin Council litigation in the English courts. 
and lawyers in his court will have studied international law and will be familiar with it, just as they are familiar with other everyday branches of the law. But there is another culture that exists, in which it is possible to become a practising lawyer without having studied international law, and indeed to become a judge knowing no international law. Psychologically that disposes both counsel and judge to treat international law as some exotic branch of the law, to be avoided if at all possible, and to be looked upon as if it is unreal, of no practical application in the real world. Of course, this attitude is mostly to be found in those countries that embrace (in so far as they think about it at all) the dualist system. It is a not unfair description of some courts in the United Kingdom. But the lack of background in international law (which is why I speak of it as a legal culture, as much as a question of legal philosophy) manifests itself in various ways, for there are individual cultures as well as national cultures. Some judges are simply rather contemptuous of everything to do with international law, which they doggedly regard as "unreal". Others are greatly impressed by international law, but feeling insufficiently familiar with it seek at all costs to avoid making determinations upon it: strenuous efforts are made not to decide points of international law, but to locate the ratio decidendi of the judgment on more familiar ground. And yet others find international law potentially relevant and important and immerse themselves in it and are fully prepared to pronounce upon it.

In New Zealand, the Law Commission became increasingly aware of the gap between the need for lawyers to know the international legal context in which they were operating and the reality of their knowledge and accordingly prepared A New Zealand Guide to International Law and its Sources. ${ }^{20}$

With the Bill of Rights there was also the particular problem that many in the legal profession thought that the Bill had been abandoned by its sponsors. It came into effect with almost no notice and to the extent that there was comment it was derisive. This was in sharp contrast, for instance, to the major debates and educational processes that surrounded the coming into force of the Canadian Charter in 1982 and the United Kingdom Human Rights Act in 1998. New Zealand in 1990 was in two senses to be compared not with Canada in 1982 but with Canada in 1960 when the Diefenbaker Bill of Rights was enacted - a non-entrenched measure enacted amidst considerable scepticism.

But by 1990 in New Zealand important general changes in legal and judicial control over the administration and in expectations of the judicial role had occurred. Also relevant were the efforts of a number of judges, academics, practitioners and lawyers within the law reform and policy processes, several of whom had undertaken postgraduate studies in

20 New Zealand Law Commission R34 (NZLC, Wellington, 1996). 
the United States. ${ }^{21}$ The attitudes reflected in those efforts may be seen as being among the reasons that the Bill now has a substantial impact. It is interesting to compare, for instance, the flat opposition of Sir Richard Wild as Solicitor-General in 1963 to the proposal for a Bill of Rights at that time ${ }^{22}$ with the supportive attitudes of Sir Owen Woodhouse and Sir Robin Cooke, the Presidents of the Court of Appeal in the late 1970s and 1980s. ${ }^{23}$ Judges in more recent times have also been assisted by extensive exchanges of information and experience within the Commonwealth, notably at the Judicial Colloquia organised by the Commonwealth Secretariat and Interights with the guiding hand of Lord Lester of Herne Hill QC. ${ }^{24}$ With other lawyers, some at least of the judges would also have been aware of the burgeoning literature around the Commonwealth. ${ }^{25}$

\section{THE ROLE OF THE BILL OF RIGHTS IN THE PREPARATION OF LEGISLATION}

The Minister of Justice, in his introduction to the White Paper on the Bill of Rights, indicated that he did not see the striking down of legislation as the major means for giving effect to the rights in it: ${ }^{26}$

The draft Bill of Rights involves giving more power to the Courts. Where any Act of Parliament, common law rule or official action is contrary to the Bill of Rights it can be declared invalid by a court. This element of the Bill of Rights is the key change in New Zealand's constitutional law. It is an important change but too much should not be made of it. Courts will only infrequently declare provisions in Acts of Parliament contrary to the Bill of Rights. In practical terms the Bill of Rights is a most important set of messages to the machinery of Government itself. It points to the fact that certain sorts of laws should not be passed, that certain actions should not be engaged in by Government. In that way a Bill of Rights provides a set of navigation lights for the whole process of Government to observe.

21 See for example K Keith "The Impact of American Ideas on New Zealand's Educational Policy, Practice and Theory: the Case of Law" (1988) 18 VUWLR 327.

22 See his evidence to the Select Committee considering the 1963 Bill (based closely on the Canadian Bill of 1960), above $n 2$.

23 For example A O Woodhouse Government under the Law (J C Beaglehole lecture 1979) and R B Cooke "Practicalities of a Bill of Rights" (1984) 112 Council Brief 4, (1986) 2 Australian Bar Rev 189, and W K Hastings (ed) F S Dethridge Memorial Addresses 1977-1988 (Maritime Law Association of Australia and New Zealand, Auckland, 1989) 71.

24 The first and latest were held in Bangalore, India, in 1988 and 1998. For a brief account of that held in Georgetown, Guyana, in 1996, see Lester "The Georgetown Conclusions on the Effective Protection of Human Rights Through Law" [1996] Public Law 562.

25 See for example that listed in the bibliography in the White Paper above $\mathrm{n} 9$.

26 White Paper above $\mathrm{n} 9$. 
And in the end I believe that will be the greatest contribution a Bill of Rights will make to improving our system of government.

That pre-enactment role was given added emphasis in the Bill as introduced and enacted in 1990. While the role of the courts was reduced by the superior law status of the Bill being replaced by an interpretative role, section 7 , as already noted, was added to require the Attorney-General to assess all proposed Bills against the rights and freedoms in the Bill and, if a breach was identified, to report it to the House of Representatives. There should, of course, be a substantial administrative process supporting those responsibilities of the first law officer. The obligation is in the first place on Ministers proposing legislation and the officials advising them. Under the Cabinet Office Manual a Minister in requesting the inclusion of the Bill in the legislative programme and then in proposing the Bill for introduction is to report on compliance with a number of matters, giving reasons if the Bill will not comply. The list of matters includes the New Zealand Bill of Rights Act 1990 and relevant international standards and obligations. ${ }^{27}$ The two may overlap and any breach of the Bill of Rights is likely also to be a breach of the International Covenant on Civil and Political Rights. That is something to which both the Human Rights Committee set up under the International Covenant on Civil and Political Rights and the AttorneyGeneral are sensitive. In its comments on the most recent New Zealand periodic report the Committee has drawn particular attention to the Attorney-General's certificates under section $7 .{ }^{28}$ The parliamentary processes have also been strengthened by changes to standing orders requiring the Attorney-General to table in the House of Representatives a paper setting out the grounds for the opinion of inconsistency. ${ }^{29}$

In 1991 the government established a procedure for the vetting of legislation by the Ministry of Justice and the Crown Law Office. ${ }^{30}$ Most of the material relevant to that process is not public; as well, the process itself, although the subject of some careful

27 Cabinet Office Manual above n 11, 122, 124 and paras 5.26-29.

28 Human Rights in New Zealand (Ministry of Foreign Affairs and Trade, Information Bulletin 54, 1995) 61-62 and 69-70.

29 Standing Orders of the House of Representatives (1996) SO 258.

30 Attorney-General "Memorandum: Monitoring Bills for Compliance with the New Zealand Bill of Rights 1990" in M Chen and G Palmer Public Law in New Zealand (Oxford University Press, Auckland, 1993) 556. 
criticism, has not been the subject of a public independent review. But, as the following five instances indicate, enough of the process is public to provide useful instruction. ${ }^{31}$

\section{Bail legislation}

Between 1991 and 1993 the government was under pressure from within and without to strengthen the law relating to violent offending. One area of controversy concerned the law of bail. The Solicitor-General has reported that the proposals which were finally included in the Bill introduced into the House at the end of 1992 were moderated by reference to the right in section 22 of the Bill of Rights not to be arbitrarily detained. We shall see (under (5) below) that one measure included in the resulting Act which received criticism from the Human Rights Committee under the International Covenant on Civil and Political Rights appears to have escaped effective scrutiny in that executive process.

\section{Police questioning}

The second instance shows that it is not only within the executive that the Bill of Rights may influence and constrain the preparation of legislation. The Law Commission, in preparing proposals in the difficult area of police powers of questioning, constantly tested them against the Bill of Rights. The Ministerial reference to the Commission indeed set as a purpose conformity with the International Covenant. The debate about the Commission's proposals, like litigation on the same matters, keeps returning to the rights as set out in the Bill and the related jurisprudence in New Zealand and abroad. ${ }^{32}$

\section{Traffic law: breath screening}

This is an instance of the operation of the Bill of Rights in parliamentary processes. The Attorney-General reporting under section 7 considered that a proposed new power of random breath screening of drivers was in breach of the prohibitions in the Bill of Rights

31 The accounts are drawn from Grant Huscroft in Huscroft and Rishworth, above n 14, ch 4; P Rishworth "Human Rights and the Bill of Rights" [1996] NZ Law Rev 298, John McGrath QC "The Bill of Rights and the Legislative Process" in The New Zealand Bill of Rights Act 1990 (Legal Research Foundation, Auckland, 1992), Paul East QC in P A Joseph (ed) Essays on the Constitution (Brookers, Wellington, 1995) 189-195, and K Keith "Road Crashes and the Bill of Rights: A Response" [1994] NZ Recent Law Rev 115. For related Canadian accounts see P Hogg and Bushell "The Charter Dialogue between Courts and Legislatures ..." (1997) 35 Osgoode Hall LJ 75 and Janet L Hiebert "Why Must a Bill of Rights be a Contest of Political and Judicial Wills? A Canadian Alternative" (1999) 10 PLR 22. One limit on the process is that it applies only when a Bill is introduced. It does not extend to amendments made to Bills when they are in the House. While that limit does not prevent Attorney-General statements in respect of such amendments, a recent decision suggests that the limit may have serious consequences; $R v$ Poumako (31 May 2000) unreported, Court of Appeal, CA565/99.

32 New Zealand Law Commission Police Questioning R31 (NZLC, Wellington, 1994). 
against arbitrary detention and unreasonable search and seizure. The legislation he criticised was however enacted unchanged. Does this mean, as some have suggested, that the section 7 process failed? I think that the opposite is the case. The Attorney-General's position was directly challenged before the Select Committee which was in possession of information and arguments bearing on the very issues in question. Did the law provide for search and seizure; if so was the proposed power of search and seizure unreasonable; even if it was, was the proposed law a limit imposed by law which was justified in a free and democratic society? These matters are obviously capable of assessment by a Court but they can also be assessed in Parliament through the Select Committee process. As it happened, that Select Committee had available to it more concrete information about the operation of such powers and a wider range of opinion than is disclosed in the judicial opinion which appeared at the time to be most in point, a judgment of the United States Supreme Court in which a similar law enacted in Michigan had been upheld.

\section{Classification of objectionable publications}

This example relating to a comprehensive rewriting of the New Zealand law on indecent publications, videos and films makes two points relating, first, to the danger of focusing on the Bill of Rights at the expense of other aspects of legal principle, and, second, to the international context in which human rights issues are increasingly to be seen. The Attorney-General reported that a provision creating an offence of strict liability for possessing material held to be objectionable was in breach of the principle against the retrospective application of criminal law. Again that opinion was challenged. After all, criminal courts constantly make decisions, after the event, whether a particular action breached the relevant law. It is indeed rare for them to rule in advance. What the principle of non-retrospectivity requires is that the assessment be made by reference to the law in force at the time. That principle was not challenged by the proposal.

Rather, what was wrong with the proposed strict liability offence in terms of legal principle, in the minds of some critics, was that actions which were entirely without fault were to be made the subject of criminal sanction. That the Bill of Rights should not be treated as a comprehensive statement of legal principle against which legislative proposals are to be tested is made clear by the Cabinet Office Manual and the report, endorsed by that Manual, of the Legislation Advisory Committee, on Legislative Change: Guidelines on Process and Content (new edition 1991).

In its comments on the most recent New Zealand periodic report under the Covenant, the Human Rights Committee questioned a different aspect of the Films, Videos and Publications Classification Act - its definition of objectionable material. The Committee saw that definition as infringing freedom of speech. Officials did in fact raise that issue with the Attorney-General but he did not report to the House on it, presumably 
concluding that the definition did not breach the freedom of speech guarantee in section 14 as read with the reasonable limits provision of section $5 .{ }^{33}$

\section{Preventive detention}

This last instance of the operation (or really the non-operation) of section 7 helps make the same point. The 1993 criminal justice reform legislation mentioned earlier under the bail heading ((1) above) also widened the availability of the sentence of preventive detention. Instead of requiring more than one offence as a prerequisite that law provided that in some circumstances the penalty could be imposed for a single very serious offence. When considering these provisions the Human Rights Committee expressed concern that the imposition of punishment in respect of future offences was inconsistent with articles 9 and 14 of the Covenant. ${ }^{34}$

The differences between the Human Rights Committee and Parliament in the two areas just mentioned relate to important issues of legal and social policy. They highlight the internationalisation of those policy issues. The national processes mentioned also demonstrate the important role a Bill of Rights can play in the advisory, executive and legislative processes and not simply in the courts. Those processes can and have become more principled and reasoned. They can and do focus better on the competing values and relevant facts. To recall a point that has also arisen in the courts, it is clear from the reports of the Attorney-General that section 5, the justified limits provision, is part of that advisory process. In that context, for instance, the Attorney and his or her advisers have made extensive use of an important early decision of the Canadian Supreme Court on the justified limits provision. ${ }^{35}$

\section{THE IMPACT OF THE BILL OF RIGHTS IN THE COURTS}

The principal impact of the Bill of Rights in the courts, at least on a day to day basis, is in the area of criminal justice. A consideration of some aspects of cases in that area can usefully be introduced by two passages in an early drink/driving case. ${ }^{36}$ Cooke $\mathrm{P}$ said this about "the approach to the Bill of Rights Act": 37

Part II of the New Zealand Bill of Rights Act sets out the rights and freedoms affirmed by the

Act. The drafting is of the kind typical of declarations of human rights, described by

33 See also Re New Truth and T V Extra (1996) 3 HRNZ 162, 176.

34 See Human Rights in New Zealand above n 28, 69. See also $R v$ Leitch [1998] 1 NZLR 420, 431.

$35 R v$ Oakes [1986] 1 SCR 103. They also refer to Noort above $n 16$.

$36 \quad$ Noort above $\mathrm{n} 16$.

37 Noort above n 16, 268. 
Lord Wilberforce giving the judgment of the Privy Council in Minister of Home Affairs $v$ Fisher [1980] A.C. 319, 328, as "a broad and ample style which lays down principles of width and generality". ... In the Fisher case, which concerned the Bermuda Constitution, Lord Wilberforce after referring to the European Convention for the Protection of Human Rights and Freedoms (1953) and the United Nations' Universal Declaration of Human Rights (1948) made the statement, now evidently destined for judicial immortality:

These antecedents, and the form of Chapter I itself, call for a generous interpretation avoiding what has been called "the austerity of tabulated legalism," suitable to give to individuals the full measure of the fundamental rights and freedoms referred to.

Richardson J, like Cooke P, quoted the title to the Act and then continued: ${ }^{38}$

Three points may be noted. First "affirm", "protect" and "promote" are all words expressive of a positive commitment to human rights and fundamental freedoms. It is in that spirit that interpretation questions are to be resolved. Second, the deliberate reference to "affirm" in the long title and in s $2 \ldots$ makes the very important point that the Act is declaratory of existing rights. It does not create new human rights. As basic human rights, the rights and freedoms referred to do not derive from the 1990 Act. In that respect it parallels the Bill of Rights Act 1689 which was declaratory of "the true, ancient and indubitable rights and liberties of the people" (section 6). That philosophical underpinning has to be taken into account when construing and applying the Bill of Rights Act provisions. Third, para (b) of the long title affirms New Zealand's commitment to internationally accepted human rights standards. As recognised in the preamble to the International Covenant on Civil and Political Rights, human rights "derive from the inherent dignity of the human person" and States party to the Covenant are obliged "to promote universal respect for, and observance of, human rights and freedoms".

Next, any reading of the 1990 Act brings out its special characteristics. Some have already been noticed. Two more should be mentioned. First the statement in Part II of civil and political rights is in broad and simple language. No doubt that is to emphasise the importance which Parliament attaches to their clear expression. It calls for a generous interpretation suitable to give individuals the full measure of the fundamental rights and freedoms referred to (Minister of Home Affairs v Fisher [1980] AC 319, 328).

The second is the recognition of limitations on the absoluteness and generality of the rights and freedoms affirmed in the Act. This reflects the fundamental consideration that individual freedoms are necessarily limited by membership of society and by duties to other individuals and to the community. That consideration is also reflected in the statement in the preamble to

38 Noort above n 16, 277. 
the International Covenant on Civil and Political Rights that an individual has "duties to other individuals and to the community to which he [or she] belongs".

He then went on to quote sections 4,5 and 6 of the Act and under the heading "Interpretation of Bill of Rights Legislation" he said this: ${ }^{39}$

To sum up at this point, the Bill of Rights Act is a legislative commitment to the protection and promise of those basic human rights and freedoms set out in the Bill. Those rights are not absolute and that commitment does not preclude Parliament from abridging or even excluding their application. Sections 5 and 6 reflect a strong legislative intention to protect the rights and freedoms contained in the Bill of Rights. In determining under section 4 whether there is an inconsistency between the provisions of another enactment and a provision of the Bill of Rights, it is proper to have regard to the statutory objectives of protecting and promoting human rights in New Zealand, and New Zealand's commitment to international human rights standards, and also to the limiting provisions of section 5 and section 6 . In the end, and in the absence of an express statutory exclusion of a Bill of Rights provision, it must be a question of determining under section 4 whether there is any room for reading along with the other enactment a Bill of Rights provision whether absolute or modified or limited pursuant to sections 5 and 6 .

These statements by senior members of the Court of Appeal indicate early positive attitudes to the new measure. There is none of the narrowness and caution that might perhaps have been expected had a similarly confined statute with a similarly difficult birth been enacted at some particular earlier times.

Others can assess the record from a greater distance than I can. Consistently with the courts' experience, this part of the paper mainly concerns criminal justice matters, but I begin with cases from two other areas - freedom of speech and the prohibition on discrimination. They provide a reminder that the Bill is not simply about the rights of suspects and defendants in the criminal justice process. They highlight as well a continuing fundamental issue of who decides what since the freedom of speech decision, Lange v Atkinson, ${ }^{40}$ has been criticised on the basis that the Court should have deferred to Parliament while the case on discrimination, Quilter $v$ Attorney General, ${ }^{41}$ has produced the opposite complaint of undue deference to political processes. Some might also see the latter case as involving a departure from the early attitude to the Bill but others might

39 Noort above n 16, 278.

40 Lange v Atkinson [1998] 3 NZLR 42 (CA); see also [2000] 1 NZLR 257 (PC) and (21 June 2000) unreported, Court of Appeal, CA52/97.

41 Quilter v Attorney General above n 10. 
think the approach adopted by some of the judges as appropriate given the nature of the issues and the particular non-discrimination provision included in the Bill. ${ }^{42}$

In the latter case three lesbian couples who wished to marry challenged refusals to issue marriage licences. The Court was unanimous that same sex marriages were not provided for in the Marriage Act - with the consequence that any breach of rights under the Bill would be sanctioned by section 4 . The members of the Court nevertheless went ahead and considered the question whether the Bill's prohibition on discrimination was breached. They divided. Their different approaches can be related to different views of the relative roles of judge and legislator in developing the law in such areas and, more concretely, raise the question whether the judicial developments are to be by way of the particular incidents or consequences of status or by altering the status itself. The judgments may also be assessed in terms of the sources on which they draw - including legislation, judicial decisions, scholarly writings and international texts. Some of the apparent or even actual certainties that once arose from more confined sources of law and argument have gone. That change is not simply a change in practice, relating to the greater accessibility of burgeoning sources. It is a consequence or aspect of what an outstanding English academic lawyer has recently identified as the challenges to the law presented by a flat, secular, plural, sophisticated democracy. "Our law lives in a new world. It has burdens which it never bore before, in the simple hierarchical society of the years, and centuries, before the war." 43

A similarly wide range of sources is also to be seen in the political defamation case. They extend to the literary with Areopagitica and to political philosophy with John Stuart Mill. In that case a unanimous court held that the defence of qualified privilege could protect the maker of certain statements about those engaged in parliamentary politics. The relevant principles - which might have wider application - build on broad common law conceptions, on the nature of our democratic constitution and on freedom of expression as demonstrated in a range of situations in New Zealand and elsewhere - as well as on the right to reputation. The court answered negatively the question whether it should leave the issue to Parliament, noting among other things that Parliament had for at least two centuries essentially left the matter to judicial clarification, application and development.

Many of the cases in the criminal justice area concern police powers of search and seizure. A 1996 judgment of the Court of Appeal brought together, on the basis of 25 cases decided in that court in the previous six years, a list of relevant principles and

42 See the discussion in P Rishworth "Reflections on the Bill of Rights after Quilter v Attorney-General" [1998] NZ Law Rev 683.

43 Peter Birks "The Academic and the Practitioner" (1998) 19 Legal Studies 397, 402. 
considerations. ${ }^{44}$ One reason for that course was to reduce the uncertainty arising from that range of decisions. The tenth item in the list reads:

The Bill of Rights is not a technical document. It has to be applied in our society in a realistic way. The application and interpretation of the Bill must also be true to its purposes as set out in its title of affirming, protecting and promoting human rights and fundamental freedoms in New Zealand, and affirming New Zealand's commitment to the International Covenant on Civil and Political Rights. The crucial question is whether what was done constituted an unreasonable search or seizure in the particular circumstances. Anyone complaining of a breach must invest the complaint with an air of reality and must lay a foundation for the complaint before the trial court by explicit challenge or cross-examination or evidence.

That proposition refers both to the international context of the Bill of Rights and to its requirement of realistic assessments. Such elements also appear in propositions (5) and (6):

5. A prime purpose of section 21 [stating the right to be free from unreasonable search and seizure] is to ensure that governmental power is not exercised unreasonably. A section 21 inquiry is an exercise in balancing legitimate state interests against any intrusions on individual interests. It requires weighing relevant values and public interests.

6. The guarantee under section 21 to be free from unreasonable search and seizure reflects an amalgam of values. A search of premises is an invasion of property rights and an intrusion on privacy. It may also involve a restraint on individual liberty and an affront to dignity. Any search is a significant invasion of individual freedom. How significant it is will depend on the circumstances. There may be other values and interests, including law enforcement considerations, which weigh in the particular case.

Contemporary society attaches a high value to privacy and to the security of personal privacy against arbitrary intrusions by those in authority. Privacy values underlying the section 21 guarantee are those held by the community at large. They are not merely the subjective expectations of privacy which a particular owner or occupier may have and may demonstrate by signs or barricades.

Reasonable expectations of privacy are lower in public places than on private property. They are higher for the home than for the surrounding land, for farm land and for land not used for residential purposes. And the nature of the activities carried on, particularly if involving public engagement or governmental oversight, may affect reasonable expectations of privacy. An assessment of the seriousness of the particular intrusion involves considerations of fact and

$44 \quad R v$ Grayson and Taylor [1997] 1 NZLR 399 (CA); the Privy Council refused leave to appeal. For critical comment see A Butler "The End of Principle and Precedent in Bill of Rights Cases?" [1997] NZ Law Rev 274 and Schwartz, above n 15. 
degree, not taking absolutist stances. In that regard, and unlike the thrust of the American Fourth Amendment jurisprudence, the object of section 21 is vindication of individual rights rather than deterrence and disciplining of police misconduct.

A second major area of dispute has been police questioning. One early matter of difficulty was the temporal one. At what point does a person fall within the language "who is arrested or who is detained under any enactment"? 45 It is at that point that a suspect becomes entitled to certain rights, especially to be informed of the reason for the arrest or detention, to have the right to consult and instruct a lawyer without delay and to be informed of that right, and to have the right to refrain from making any statement and to be informed of that right. The Law Commission has proposed that Parliament spell out police powers of questioning in more detail. Practical questions also arise about support for the rights, especially through legal aid.

The right to an early trial has presented a third set of challenges to the courts and to the courts' administration. The Court of Appeal in Martin v Tauranga District Court ${ }^{46}$ gave substance to the right by stopping a prosecution which it considered had taken too long to get to trial. Again this right, as stated in the Bill of Rights, can be seen as long existing in the common law as well as being recognised in international law. One practical consequence of the case has been to focus the attention of the new Department for Courts and others responsible on the need to ensure that facilities and judges are available to ensure that criminal prosecutions proceed promptly.

A fourth area of contention has concerned the media and criminal trials in contempt proceedings and in access to court records. In a 1996 judgment, concerning access to evidence which had been held inadmissible in a major murder trial, the Court of Appeal in ordering the release of the information called not only on the provision of the Bill of Rights about public hearings but also on the relevant provisions of the International Covenant and on judicial statements of the values underlying freedom of speech. ${ }^{47}$

A final matter of major difficulty concerns the consequences of breach. In Grayson and Taylor, the Court of Appeal indicated that on an appropriate occasion it would be prepared to re-examine the prima facie exclusion rule for evidence obtained in breach of the Bill of Rights. As the Court says, one remedy available for violations of the Bill of Rights is monetary damages or compensation. In a wide range of possible cases damages will be available in terms of the regular tort liability of the public agencies involved for trespass,

45 See for example: $R v$ Butcher [1992] 2 NZLR 257; $R v$ Goodwin [1993] 2 NZLR 153 and 390.

46 Martin v Tauranga District Court [1995] 2 NZLR 419 (CA).

47 Television New Zealand Ltd $v$ R [1996] 3 NZLR 393 (CA). For a contempt of court decision, balancing the competing values, see Gisborne Herald Co Ltd $v$ Solicitor-General [1995] 3 NZLR 563. 
assault or wrongful imprisonment. But in some cases there may be no remedy in tort available either because of the area of law involved or because of an immunity or protection provision in the relevant legislation. The Court of Appeal held in Baigent's $\mathrm{Case}^{48}$ that in such a situation monetary compensation was available for the breach of the Bill of Rights.

In reaching the conclusion that a person whose rights under the Bill of Rights have been breached could seek compensation, four members of the Court drew on the text of the Bill (which is silent on the matter of remedies), established common law principle (where there is a right there is a remedy), relevant foreign case law, and New Zealand's international obligations. As well, all members of the Court were also willing to use standard methods of statutory interpretation to read down immunity or protective provisions in legislation, to permit actions in trespass.

More recently, members of the Court have addressed the question, amidst some controversy, whether the Court could and should make declarations of inconsistency in the event that a statutory provision cannot be reconciled with the statement of rights in the Bill. ${ }^{49}$

\section{SOME LESSONS AND QUESTIONS}

Some of the lessons suggested by the story of the Bill of Rights over the last 30 or 40 years are also to be seen in other major constitutional changes which have occurred over the same period and to which, as well, University colleagues ${ }^{50}$ contributed in a range of ways: they include the development of the Office of the Ombudsman, reform of the state services early and later in the period, the National Development Conference and related processes, environmental policies, the place of the Treaty of Waitangi, the Official Information Act, control over regulation making, corporatisation and privatisation, the electoral system, law reform and treaty making processes.

A first lesson, relating to the occasion for this essay, concerns the role of the academic as "critic and conscience of society" - to quote the 1990 university legislation. I mention three aspects: the constructive critical role (for instance through submissions on legislation and law reform proposals and as members of advisory bodies, as well as through academic

48 Simpson v Attorney-General [Baigent's Case] [1994] 3 NZLR 667 (CA).

49 Moonen $v$ Film and Literature Board of Review above $\mathrm{n} 15$ and $\mathrm{R} v$ Poumoko above $\mathrm{n} 31$.

50 Naming names can be invidious but consider these members of related departments from the mid 1960s to the mid 1970s: C C Aikman, R M Alley, G P Barton, J C Beaglehole, T H Beaglehole, R H Brookes, L V Castle, R S Clark, L Cleveland, F W Holmes, D L Mathieson, R G Mulgan, G W R Palmer, A B Quentin-Baxter, R Q Quentin-Baxter, I L M Richardson, A D Robinson, J L Robson, F L W Wood, as well as J L Roberts. 
writing published in the journals and books); empirical research (for instance about the practical impact of the Bill of Rights on police practice ${ }^{51}$ and on the preparation of legislation); and, to adapt Mathew Arnold, the capacity to see a matter steadily and to see it whole.

Other lessons are applications of that final aspect: one is that the Bill of Rights and the related international texts are, of course, entwined with the common law and extensive statutory regimes. This paper runs the risk, demonstrated by the controversy over the censorship legislation mentioned earlier, of isolating the Bill of Rights from other elements which have historically constituted our law. As Lord Cooke said in 1986, much of what an entrenched Bill of Rights could accomplish was capable of being achieved by the common law already. A wholly new power relationship between the courts and Parliament was probably unlikely. ${ }^{52}$ But the Bill undoubtedly gives greater emphasis to the rights it affirms. So the former Solicitor-General, in a recent paper on contempt of court and the media, sees the Court of Appeal as rejecting any idea that the law of contempt can be seen as standing unaffected by or prevailing over the Bill of Rights. ${ }^{53}$

Another aspect of making a broader assessment is to determine the significance of the decision made to have an interpretive rather than entrenched Bill by drawing on the experience not just of New Zealand but also of other countries: an entrenched Bill of Rights might rarely result in statutes being struck down (as in the United States throughout the 19th century); or statutes might be struck down relatively often (as with the Canadian Charter); or, if that does happen, the invalidation might frequently be reversed by constitutional amendment (as in Zimbabwe). It might also be said that the

51 As a consequence of the Bill of Rights are the guilty not being charged or are they being acquitted because of the rules and in what numbers? How do we now see the Blackstonian dictum that it is better that 12 guilty people go free than one innocent is wrongly convicted? One particular international acceptance of that possible consequence is highlighted in the Convention on Torture, article 15 of which provides that any statement which has been made as the result of torture may not be invoked as evidence in any proceedings, except of course against a person accused of torture. For a recent consideration by the Privy Council see Mohammed $v$ The State [1999] 2 WLR 552.

52 [1986] NZLJ 148.

53 J McGrath "Contempt and the Media : Constitutional Safeguard or State Censorship?" [1998] NZ Law Rev 371, 383. 
possible extent of interpretive approaches has yet to be fully tested, and that the United Kingdom's experience of its Human Rights Act 1998 will surely be instructive. ${ }^{54}$

The question whether the Bill should be entrenched (as the Human Rights Committee set up under the ICCPR has suggested) sharpens issues about the use of courts to pursue political purposes - or rather their more extensive use in that way, for there are many instances of political cases in many jurisdictions down the centuries. ${ }^{55}$ As the perception of a court's political role is heightened, greater attention focuses on the judicial appointment process and matters of tenure. Again there is much relevant foreign experience. ${ }^{56}$

The external reference is of course not simply to other national courts, legislatures, law reform bodies and commentators. Equally or more importantly it is to the relevant human rights treaties. New Zealand courts refer to them and to the interpretation given to them in determining the meaning of related provisions of the Bill of Rights. Those treaties relate as well to the entrenchment issue. The powers of the New Zealand legislature, emphasised by section 4 of the Bill, may not be all that they appear given that very extensive body of international obligation. To draw on earlier discussions, it can be said that when the Bill is seen in its international context we have a super Bill rather than a full or half-full Bill. ${ }^{57}$ Such a view gains support from the opinions of the Human Rights Committee and the United Nations Secretary-General expressed in the context of North Korea's purported withdrawal from the International Covenant on Civil and Political Rights and of an Australian Attorney-General that States which are party to the two international covenants have no right of unilateral withdrawal from the obligations to

54 For an early sign see $R v$ Director of Public Prosecutions [1999] 3 WLR 175 (CA). In his recent review of the first decade of operation of the Bill of Rights one commentator suggests that New Zealand's unentrenched, interpretive Bill of Rights has been treated by the courts as a constitutionalised, entrenched Bill of Rights : J Allan “Turning Clark Kent into Superman : the New Zealand Bill of Rights Act 1990" (2000) 9 Otago Law Review 613.

55 See for example C Harlow and R Rawlings Pressure through Law (Routledge, London, 1992) and Keith "The Advisory Jurisdiction of the International Court of Justice" (1996) 17 Aust YBIL 39 (referring to the early $17^{\text {th }}$ century Case of Prohibitions, slavery cases in the $18^{\text {th }}$ and $19^{\text {th }}$ centuries and the then pending requests to the ICJ for advisory opinions about the lawfulness of the use of nuclear weapons).

56 See for example Sir Geoffrey Palmer "Judicial Selection and Accountability: Can the New Zealand System Survive?" in B D Gray and R B McClintock (eds) Courts and Policy: Checking the Balance (Brookers, Wellington, 1995) 11. Changes involving wider participation and greater transparency in the appointment processes have been made in the last year with the full support of the judiciary. See The Report of the New Zealand Judiciary 1998 (Department for Courts, Wellington, 1999).

57 See for example K Keith "A Bill of Rights: Does it Matter? A Comment" (1997) 32 Texas ILJ 393. 
which they committed themselves. No such right is expressly provided for as it is, for instance, in the European Convention on Human Rights; and, in accordance with the law declared in the Vienna Convention on the Law of Treaties, it appears that no power of withdrawal could be implied. ${ }^{58}$

The interaction between the various sources of law and influence and their constraining effect is demonstrated by Baigent's Case and its aftermath. The conclusion that as a matter of law there is a monetary remedy and that as a matter of policy there must be one is given added force by the comments of the Human Rights Committee on New Zealand's latest periodic report under the Covenant. Indeed the Committee went further in proposing that the remedy should have statutory or even entrenched constitutional force. Finally, the Law Commission, following a review requested by the government, has concluded, essentially for the reasons given by the Court of Appeal, but on the basis of much more extensive information, that the remedy should remain. ${ }^{59}$ Those interrelated processes help emphasise the stability of the Bill as also appears from the fact that the Bill has remained unchanged over the last decade, except for an amendment to the prohibition on discrimination to align it with the Human Rights Act 1993.

The increasing internationalisation of much law-making extends far beyond human rights law. About one third of all New Zealand public statutes give effect to or bear on international obligations binding on New Zealand. In 1998 alone Parliament enacted the following statutes which give effect to treaties and other international agreements :

- Accident Insurance Act (personal injury liability conventions and ILO conventions);

- Antipersonnel Mines Prohibition Act;

- Appropriation statutes (memberships of international organisations);

- Copyright (Removal of Prohibition on Parallel Importing) Amendment Act;

- Crimes (Internationally Protected Persons and Hostages) Amendment Act (1994 Convention on Safety of UN and Associated Personnel);

- Customs and Excise Amendment Acts;

- Diplomatic Privileges and Immunities Amendment Act;

58 (1995) 16 Aust YBIL 470-471 and G Palmer "Human Rights and the New Zealand Government's Treaty Obligations" (1999) 29 VUWLR 57, 64-65.

59 New Zealand Law Commission Crown Liability and Judicial Immunity: A Response to Baigent's Case and Harvey v Derrick R37 (NZLC, Wellington, 1997). 
- Extradition Amendment Act;

- International Finance Agreements Amendment Act;

- $\quad$ Land Transport Act (conventions on road transport);

- Maritime Transport Amendment Act (pollution liability and tonnage convention);

- Misuse of Drugs Amendment Act (1998 Vienna Convention on Psychotropic Drugs);

- Mutual Assistance in Criminal Matters Amendment Act (protection and drugs conventions);

- Postal Services Act (Universal Postal Union and Asia Pacific Postal Union);

- $\quad$ Trade in Endangered Species Amendment Act.

One consequence of the increasing recognition that the real power to make law is often offshore is the call in Australia, the United Kingdom and New Zealand for greater openness in treaty making and treaty acceptance. That call has produced changes in all three countries, especially in respect of the process for the acceptance of treaties in the direction of a greater parliamentary role. ${ }^{60}$ But those changes cover only one part of the overall process, and extensive professional and public education remains necessary.

The final lesson, or really question, concerns the allocation of law making power in these basic areas of human rights and criminal procedure. Who should do what? ${ }^{61}$ The actors include the international community in its various forms, the people through formal constitutional processes, Parliament, public agencies (especially the police, for instance, in their general instructions), the courts and the scholarly communities. While bills of rights are often seen as conferring new and, to some, inappropriate powers on courts, the process for the enactment of a bill of rights can mean that the legislature is itself prescribing those fundamental rules, sometimes for the first time. (The legislative process may be an enhanced one, involving for instance extensive consultation and popular referenda.) In

60 For New Zealand see the Report of the Foreign Affairs, Defence and Trade Committee Inquiry into Parliament's Role in the International Treaty Process [1997] AJHR I 4A 8-9, New Zealand Law Commission The Treaty-Making Process (NZLC, Wellington, 1997), the Government response to the Committee Report [1998] AJHR A5 and the related debate and decisions of the House of Representatives, (28 May 1998) NZPD 9419-9443.

61 For a valuable comparative consideration see Leslie Zines Constitutional Change in the Commonwealth (Cambridge University Press, New York, 1991) ch 2. In this paper I do not consider the consequences of the privatisation of much power that was previously public. See for example Strange, above $\mathrm{n} 8$. 
that way and others, one principal purpose or effect of a Bill of Rights can be, and indeed should be, to reinforce democratic and responsible processes.

Already, the brief New Zealand experience of its Bill of Rights provides rich material calling for further scholarly attention and rebutting, as would John Roberts, Alexander Pope's apparent cynicism in his Essay on Man: "For Forms of Government let fools contest; Whate'er is best administered is best". 62

62 An Essay on Man (1733-34), Epistle III; “apparent" cynicism because Pope was looking for both better forms and better administration; see for example William Warburton's 1751 note in William K Wimsat (ed) Alexander Pope Selected Poetry and Prose (2 ed, Holt, Rinehart and Winston, New York, 1972) 219-220 n 15, quoting Pope : "no form ... in itself can be sufficient to make a people happy, unless it be administered with integrity". 